\title{
APPLICATION OF A DOUBLE LAYER SAND FILTER WITH A PUR FOAMS LAYER IN THE TREATMENT OF DOMESTIC SEWAGE WITH AN INCREASED CONTENT OF AMMONIA NITROGEN
}

\author{
Ewa Dacewicz ${ }^{1 \bowtie}$, L'uboš Jurik² \\ ${ }^{1}$ Chair of Sanitary Engineering and Water Economy, Faculty of Environmental Engineering and Land Surveying, University of \\ Agriculture in Krakow, al. Mickiewicza 24/28, 30-059 Krakow \\ 2 Faculty of Horticulture and Landscape Engineering, Slovak University of Agriculture in Nitra, 2 A. Hlinku street, 94976 Nitra
}

\begin{abstract}
Aim of the study

The aim of the study was to determine the possibility of using PUR polyurethane foams as an upper layer of sand filter for the treatment of domestic sewage with an elevated concentration of ammonia nitrogen

Material and methods

The working of filtration beds factory-filled with a new stiffened filling or with mechanically ground PUR waste was compared. The efficiency of removal of the septic tank pre-treated organic and biogenic compounds as well as of total suspended solids and pathogenic bacteria from sewage with a hydraulic load varying from 31.8 to $229.2 \mathrm{~mm}^{3} \cdot \mathrm{mm}^{-2} \cdot \mathrm{d}^{-1}$ was determined.

\section{Results and conclusions}

It was shown that after ten months of working, polyurethane and sand filters filled in the upper layer with pieces of polyurethane foam in casings, achieved high efficiency of organic substance removal $\left(\mathrm{BOD}_{5}\right.$ reduction by $88 \%$ on average and $\mathrm{COD}_{C r}$ by $66 \%$ ). The use of polyurethane waste in the upper layer of the filter bed made it possible to remove $\mathrm{N}_{-} \mathrm{NH}_{4}^{+}$ions by an average of $78 \%$, whereas single-layer sand filters proved to be equally effective only in the first two stages of the research. It was found that the additional filling of vertical flow filters in the form of PUR foam clipping placed in casings provided favourable conditions for the development of both heterotrophic bacteria and nitrifying bacteria without the need for additional aeration. The applied upper layer of foams in combination with the lower layer of sand allowed for a very high removal of pathogenic bacteria: Escherichia coli on average 98.8\%, while coliform bacteria on average 95.0\%.
\end{abstract}

Keywords: polyurethane foams, wastes, sand filter, domestic sewage treatment

\section{INTRODUCTION}

In some countries of Africa, Latin America or Asia, with a large population and low water consumption per capita, raw sewage turns out to be more concentrated than typical domestic sewage in highly developed countries. This results in the concentration of pollutants in sew- age located in holding tanks or flowing out from septic tanks, exceeding the values presented in the literature (Tchobanoglous et al., 2003; Ehsas, 2013).

Treatment of concentrated sewage with conventional activated sludge technology is very costly, especially with regard to operating costs since aeration costs grow linearly with the increase of organic load

凶e-mail: ewa.wasik@urk.edu.pl 
rate (OLR) in concentrated sewage. In recent years, there has been interest in less conventional methods such as combining a UASB reactor with a DHS reactor or a CFID type SBR reactor (Khan et al., 2013).

Also, waste and their management is a serious problem in rapidly growing countries. Polish legislation in the 2012 Waste Management Act adapted to the EU requirements (article 3, paragraph 1, point 2) defines the concept of waste management as collection, transport and processing of waste (Ustawa ... of 2012).

One of the methods of waste management is their recovery. That means any process main result of which is the waste serving a useful purpose by replacing other materials that would otherwise be used to perform a given function or as a result of which the waste is prepared to meet such a function in a given plant or in the economy in general (article 3, paragraph 1, point 14). Additionally, the legislator found that recycling is a way of recovery, under which the waste is processed into products, materials or substances used for its original purpose or other purposes (art. 3, item 1, point 23) (Ustawa ... of 2012).

A particularly troublesome issue is the storage of waste, which covers a large area and is not biodegradable, which is why the time of their storage on landfills can be up to several dozen years. Used polyurethane foams characterized by low material density is this kind of waste. They are found in many everyday products, e.g. in the form of sponges filling upholstered furniture or in refrigeration equipment. A significant source of polyurethane foam waste is used motor vehicles: armchairs, headrests, armrests and soundproofing elements (Plastech ... 2019).

It is estimated that over 20,000 tonnes of flexible foam and over 10,000 tonnes of rigid foam waste are created annually in Poland. The vast majority of this waste is disposed to landfills or thrown away into the so-called wild dumps (Plastech ... 2019). Therefore, for both ecological and economic reasons, PUR foams should be recovered and re-used. An example of upholstery foam cuttings management can be using them as fillings, e.g. in pillows or toys. Polyurethane foams can be recycled using three types of methods: mechanical (reusing building and equipment insulation foam), chemical (performing foam glycolysis and using glycolysate to repeat the synthesis of polyurethane), en- ergy (recovering some energy by burning foams in special ovens) (Papiński and Żabski, 2012).

In this paper, the possibility of using polyurethane foams was determined, not only in its brand new and unused form, but also in the form of waste as a microorganism biomass carrier. They were used as the top filling of a double layer sand filter with vertical flow used in the system with a septic tank for the treatment of domestic sewage. A single layer filter with sand filling is a common solution used in household sewage treatment plants (Pawełek and Bugajski, 2017). Vertical flow sand filters are designed as filter beds or ditches (Błażejewski, 1994). In sand filled filters, besides filtration and sorption, biodegradation of easily decomposable organic and nitrogen compounds takes place (Heidrich et al., 2008). These processes result in the formation of a filter cake and organic clogging layer, which may eventually lead to complete clogging of the filter. According to Spychała and Nieć (2013), this phenomenon is largely related to the fibres of toilet paper present in sewage flowing out of the septic tank. Chmielowski and Ślizowski (2008) pointed out that a filter filled with sand grains of hydraulic diameter $d_{10}<0.28 \mathrm{~mm}$ will clog.

Continuous sand filters are characterized by poor ventilation because they contain a small volume of gas-filled (air) pores, which is why sewage flowing through the pores is poorly oxygenated. In order to increase the filter's efficiency in terms of removing organic and biogenic compounds and preventing them from clogging, the sand filling can be replaced partially or entirely by porous materials. Kalenik (2014) proposed the use of a supporting layer in the form of a porous filling, i.e. clinoptilolite, in a ground bed filled with intermediate sand. An interesting example are materials made of plastics, which are characterised by a high specific surface area and a low clogging tendency (Dacewicz and Chmielowski, 2018). In the case of a porous biomass carrier in the form of polyurethane sponges of $80-90 \%$ porosity, air flows around the carrier material, around which large air-filled surfaces can be seen (Jowett and McMaster, 1995). Since the 1990 s, work on the so-called downflow hanging sponge (DHS) for pre-treating sewage discharged from the UASB reactor is carried out. So far, six generations of sponges used in the DHS technology have been tested in a low strength sewage treatment (Tandukar et al., 2007; Tawfik et al., 2010b; Onodera et 
al., 2014a, 2014b; Lemura et al., 2016; Miyaoka et al., 2017). In order to avoid deforming of the spongy material and adhering one element to the other, they were installed in segments or packed in a plastic casing.

The article discusses the possibility of using polyurethane foams as an upper layer of a sand filter for the treatment of domestic sewage with an increased content of ammonia nitrogen. The influence of the type of filtration layer on the efficiency of removing organic compounds, biogenic compounds, total suspended solids and pathogenic bacteria in filtration beds at variable hydraulic load was presented.

\section{EXPERIMENTAL SECTION}

\section{Materials}

As experimental filters, vertical flow filter models were tested on a semi-technical scale. The research model consisted of five identical columns made of PVC with a diameter of $10 \mathrm{~cm}$ and a height of $100 \mathrm{~cm}$. At the bottom of each filtration layer a grate supporting the bed was located.

The columns were filled with polyurethane sponges in the form of brand new stiffened cylinders (column 1) and in the form of polyurethane (PUR) foam wastes in random shapes (columns 2 and 3) (see: Fig. 1a). This material was a mixture of elastic PUR material cuttings in random shapes, measuring 3 to $35 \mathrm{~mm}$. Their nominal diameters $d_{10}$ and $d_{60}$ were 4 and $10 \mathrm{~mm}$ respectively, and the value of the coefficient of uniformity $d_{60} / d_{10}$ was 2.5 . PUR foams are commercially used in the furniture industry (so-called comfort foam), in the automotive industry (so-called technical foam) and as packaging dividers. According to the information provided by the manufacturer, foams used in the automotive industry are both polyester and polyether with stiffness from 1.05 to $5.8 \mathrm{kPa}$ and bulk density from 13.5 to $40.0 \mathrm{~kg} \cdot \mathrm{m}^{-3}$ (Eurofoam ... 2018). Bulk density of the waste foams used was lower than of the new ones and ranged from 9.4 to $16.0 \mathrm{~kg} \cdot \mathrm{m}^{-3}$. Flexible PUR foam waste was characterized by a high presence of open pores, hence their porosity was $94.6 \%$.

Spongy structure materials have the capability to absorb water, and their high porosity allows for the settlement of microorganisms. This causes the mass of sponges to increase, and their structure can change by shape deformation. For this reason, foam cuttings were additionally located in plastic corrugated PVC casings (column 3) (see: Fig. 1b). The thickness of the spongy filling layer in columns $1-3$ was $60 \mathrm{~cm}$,
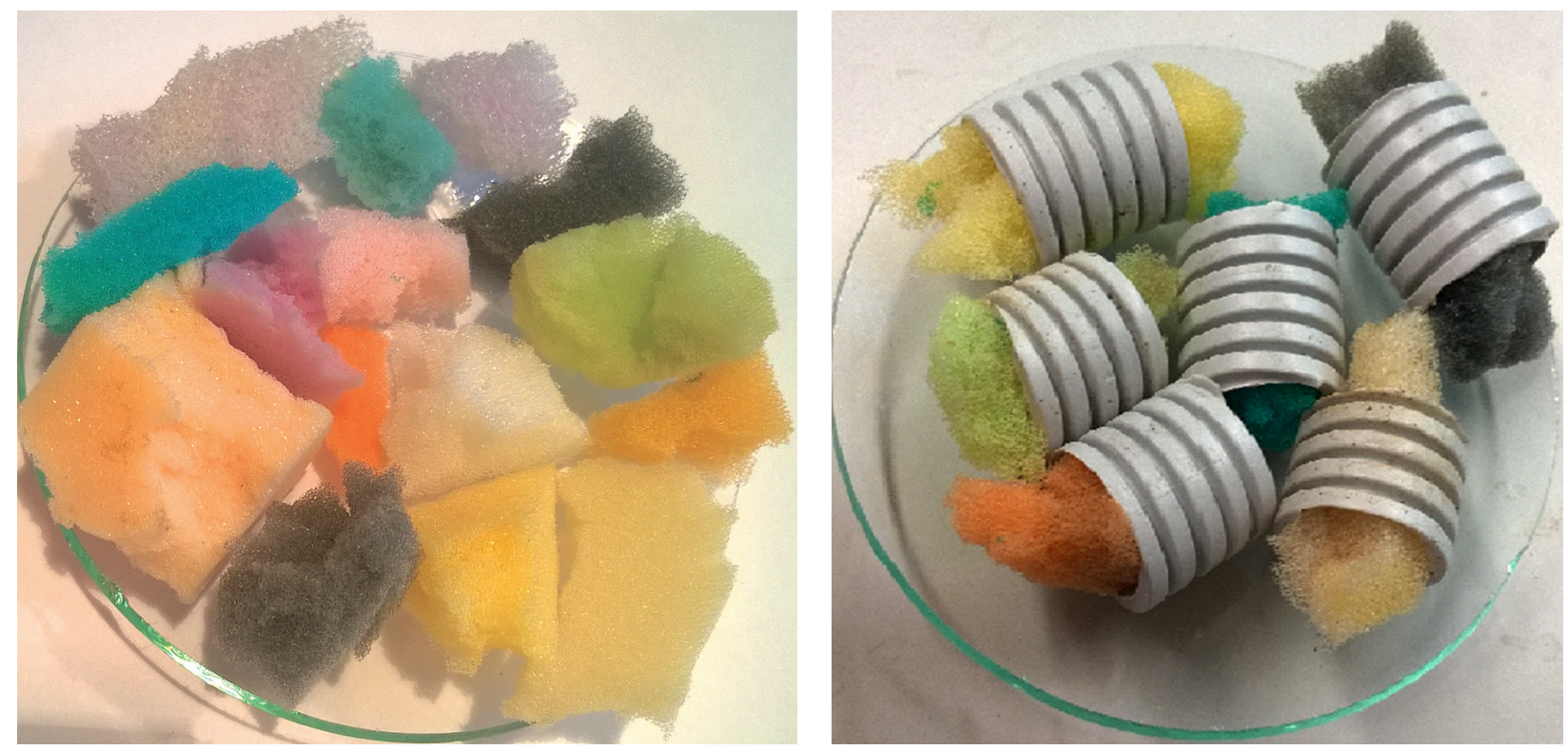

Fig. 1. Polyurethane foam cuttings used as filter beds filling a) without casings, b) in casings 
while the lower layer consisting of quartz sand with a hydraulic diameter $d_{10}=0.32 \mathrm{~mm}$ and a thickness of $30 \mathrm{~cm}$. Columns 4 and 5 acted as comparative columns and were filled with quartz sand with hydraulic diameter $d_{10}=0.32 \mathrm{~mm}$, respectively, with a thickness of $60 \mathrm{~cm}$ and $30 \mathrm{~cm}$.

\section{Research methodology}

The research was carried out using sewage flowing out of the septic tank, which then is pre-treated and transported to an intermediate tank. The outflow from the tank was discharged to the upper layer of the columns, and then it was flowing down under the influence of gravity (see: Fig. 2). Dosing of sewage to the columns

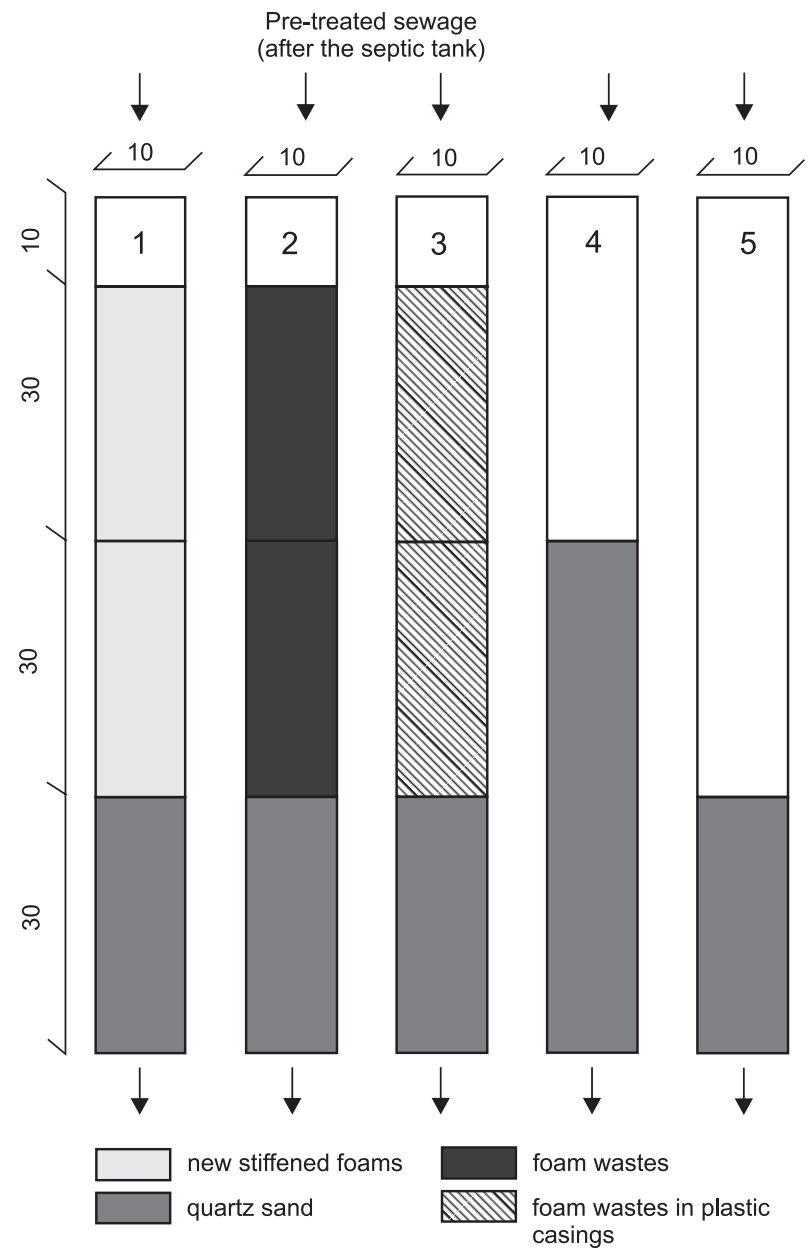

Fig. 2. The technological scheme of the research model, composed of columns $1-5$ of various types and thickness of the filling of the model was carried out using peristaltic pumps, which were turned on cyclically every hour (24 dosages per day). Each column of the test model was subjected to the same hydraulic surface loading rates in one of four stages, which changed every 6 weeks for a ten-month study period. The hydraulic surface loading was implemented in the following variants: $76.4 \mathrm{~mm}^{3} \cdot \mathrm{mm}^{-2} \cdot \mathrm{d}^{-1}$ (I and IV), $114.6 \mathrm{~mm}^{3} \cdot \mathrm{mm}^{-2} \cdot \mathrm{d}^{-1}$ (stage II) and $229.2 \mathrm{~mm}^{3} \cdot \mathrm{mm}^{-2} \cdot \mathrm{d}^{-1}$ (stage III). Due to the inoculation of the columns with activated sludge, the period of filter development has been reduced to 1 week.

\section{Analytical methods}

The pre-treated sewage was collected from a separating chamber located after the septic tank, and the cleaned sewage (filtrates) were collected from the individual columns of the model. Sewage samples were subjected to physico-chemical analysis for the following contamination indicators: $\mathrm{pH}$, dissolved oxygen, $\mathrm{BOD}_{5}, \mathrm{COD}_{\mathrm{Cr}}$, total suspended solids, ammonia nitrogen, orthophosphates, pathogenic group of coli. Physico-chemical and bacteriological analysis was carried out in one stage for an average of seven measurement series.

Measurements of the reaction and dissolved oxygen concentration were made with the ELMETRON CPO-401 multiparameter meter (PN-EN 5814:201304 standard). The $\mathrm{BOD}_{5}$ indicator's indication was determined using a manometric method with the OXITOP ${ }^{\circledR}$ bottle set (PN-EN 1899-1:2002 standard). Determination of $\mathrm{COD}_{\mathrm{Cr}}$ value was carried out using the dichromate method using the Aquanal Spectro 3 photometer (PN-ISO 6060:2006 standard). The concentration of total suspended solids was determined with the method using filtration through glass fibre filters (PN-EN 872:2007 standard), and the concentration of ammonia nitrogen was determined with the direct nesslerisation method (PN-C-04576-4:1994) standard. Pathogenic group of coli (Klebsiella, Enterobacter, Citrobacter, Proteus, Escherichia coli) was determined by dilution and surface plating on ENDO medium.

Statistical analysis was performed using the Statistica 13 program. The results of the study were subjected to statistical analysis using the analysis of variance (ANOVA). As a dependent variable, the values of the 
analysed indicators of sewage pollutants, i.e. dissolved oxygen concentration, $\mathrm{BOD}_{5}, \mathrm{COD}_{\mathrm{Cr}}$, total suspended solids, ammonia nitrogen, orthophosphates, Escherichia coli and coliform bacteria, were assumed. Firstly, the normality of the distribution of variables was evaluated using the Shapiro-Wilk test $(\alpha=0.05)$. The data was then analysed for significance of differences between variances with the Leven's variance homogeneity test.

The final stage was the analysis of variance of source data aimed at comparing the differences between individual pollutants indicators in the analysed stages. For this purpose, a nonparametric counterpart for the ANOVA analysis of variance, or the Kruskal-Wallis test, was used. The difference in means for a given pair of rank groups was considered significant if the test probability (p-value) was less than 0.05 .

\section{DISCUSSION OF RESULTS}

The sewage flowing into the columns was taken from the intermediate tank in which additional organic settling of the organic sludge flowing from the septic tank occurred. Table 1 presents basic descriptive statistics of pre-treated sewage flowing to five columns of the research model.

The sewage flowing to the columns of the model were characterised by an average value of $\mathrm{COD}_{C r}$ at
$222.3 \mathrm{mgO}_{2} \cdot \mathrm{dm}^{-3}$. The values of this index ranged from $168.0 \mathrm{mgO}{ }_{2} \cdot \mathrm{dm}^{-3}$ to $696.0 \mathrm{mgO}_{2} \cdot \mathrm{dm}^{-3}$, and the coefficient of variation was 0.73 . Analysing the $\mathrm{BOD}_{5}$ values of pre-treated sewage, it should be noted that this index changed to a lesser extent than $\mathrm{COD}_{C r}(\mathrm{WN}=0.56)$ and fluctuated from $\mathrm{mgO}_{2} \cdot \mathrm{dm}^{-3}$ to $230.0 \mathrm{mgO}_{2} \cdot \mathrm{dm}^{-3}$. The average value was $113.7 \mathrm{mgO} \cdot \mathrm{dm}^{-3}$. Chmielowski et al. (2018) and Wąsik et al. (2017) examined the sewage pre-treated in the septic tank and obtained average indexes of organic compounds at a similar level. Taking into account the values of total suspended solids in the sewage flowing into the model, it was found that the coefficient of variation was at 0.56 . The average concentration of this contamination was at $72.3 \mathrm{mg} \cdot \mathrm{dm}^{-3}$. The sewage flowing out of the intermediate tank, however, was characterised by a small variability of ammonia nitrogen ( $\mathrm{WN}=0.11)$ and orthophosphates (WN $=0.18$ ). Their values varied from 151.8 to $183.3 \mathrm{mgN}$ $-\mathrm{NH}_{4}^{+} \cdot \mathrm{dm}^{-3}$ and from 44.0 to $59.0 \mathrm{mgPO}{ }_{4}^{3-} \cdot \mathrm{dm}^{-3}$, respectively. Their average value was $153.0 \mathrm{mgN}$ $-\mathrm{NH}_{4}^{+} \cdot \mathrm{dm}^{-3}$ and $43.8 \mathrm{mgPO}_{4}^{3-} \cdot \mathrm{dm}^{-3}$. The amount of ammonia nitrogen in the sewage after the septic tank shows that these values were higher than those reported by literature (Metcalf and Eddy, 1991; Henze and Comeau, 2008), and sewage can be described as concentrated.

Figure 3 presents the parameters of the works of the columns, i.e. $\mathrm{pH}$ and oxygen concentration in the

Table 1. Quality characteristics of the pre-treated sewage flowing into the columns of the model

\begin{tabular}{lccccccc}
\hline \multicolumn{1}{c}{ Indicator } & Unit & \multicolumn{5}{c}{ Basic descriptive statistics } \\
\hline & - & $\begin{array}{c}\text { Average } \\
\text { value }\end{array}$ & Median & $\begin{array}{c}\text { Maximum } \\
\text { value }\end{array}$ & $\begin{array}{c}\text { Minimum } \\
\text { value }\end{array}$ & $\begin{array}{c}\text { Standard } \\
\text { deviation }\end{array}$ & $\begin{array}{c}\text { Variability } \\
\text { coefficient }\end{array}$ \\
\hline $\mathrm{pH}$ & 7.79 & 7.78 & 8.32 & 7.12 & 0.33 & 0.04 \\
\hline Dissolved oxygen & $\mathrm{mgO}_{2} \cdot \mathrm{dm}^{-3}$ & 0.48 & 0.04 & 4.34 & 0.00 & 1.16 & 2.40 \\
\hline $\mathrm{COD}_{C r}$ & $\mathrm{mgO}_{2} \cdot \mathrm{dm}^{-3}$ & 222.3 & 168.0 & 696.0 & 50.0 & 160.2 & 0.73 \\
\hline $\mathrm{BOD}_{5}$ & $\mathrm{mgO}_{2} \cdot \mathrm{dm}^{-3}$ & 113.7 & 110.0 & 230.0 & 25.0 & 63.4 & 0.56 \\
\hline $\begin{array}{l}\text { Total suspended } \\
\text { solids }\end{array}$ & $\mathrm{mg} \cdot \mathrm{dm}^{-3}$ & 72.3 & 47.0 & 190.0 & 26.0 & 47.1 & 0.56 \\
\hline Ammonia nitrogen & $\mathrm{mg} \cdot \mathrm{dm}^{-3}$ & 153.0 & 151.8 & 183.3 & 115.7 & 16.4 & 0.11 \\
\hline Orthophosphates & $\mathrm{mg} \cdot \mathrm{dm}^{-3}$ & 43.8 & 44.0 & 59.0 & 28.5 & 7.7 & 0.18 \\
\hline Escherichia coli & $\mathrm{CFU} \cdot 100 \mathrm{~cm}^{-3}$ & $1.3 \cdot 10^{6}$ & $0.9 \cdot 10^{6}$ & $6.0 \cdot 10^{6}$ & $3.0 \cdot 10^{6}$ & $1.6 \cdot 10^{6}$ & 1.2 \\
\hline Coliform bacteria & $\mathrm{CFU} \cdot 100 \mathrm{~cm}^{-3}$ & $4.1 \cdot 10^{6}$ & $3.5 \cdot 10^{6}$ & $8.0 \cdot 10^{6}$ & $1.3 \cdot 10^{6}$ & $2.7 \cdot 10^{6}$ & 0.66 \\
\hline
\end{tabular}




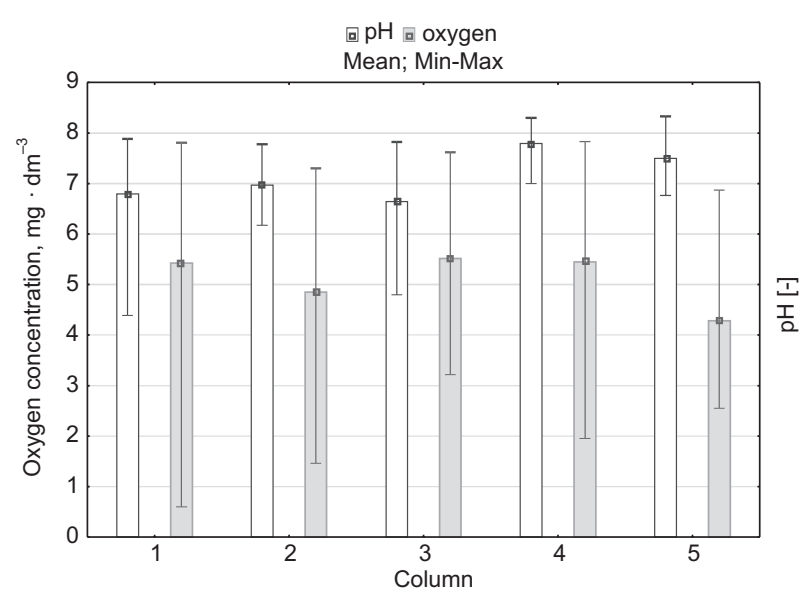

Fig. 3. The box-plot chart for $\mathrm{pH}$ and dissolved oxygen concentration in treated sewage for columns $1-5$

filtrate for the analysed research period. The sewage from the individual columns of the model were characterised by the $\mathrm{pH}$ ranging from a slightly acidic (6.64 on average in column 3$)$ to slightly alkaline (7.79 on average in column 4). Despite the very low oxygen content in the sewage flowing to the research model (Table 1), the filtrates were characterised by a similar average dissolved oxygen (DO) concentration of $5.43 \mathrm{mgO}_{2} \cdot \mathrm{dm}^{-3}$ (column 1), $4.85 \mathrm{mgO}_{2} \cdot \mathrm{dm}^{-3}$ (column 2) and $5.51 \mathrm{mgO}_{2} \cdot \mathrm{dm}^{-3}$ (column 3). For comparative columns 4 and 5 , the oxygen concentration was $5.45 \mathrm{mgO}_{2} \cdot \mathrm{dm}^{-3}$ and $4.28 \mathrm{mgO}_{2} \cdot \mathrm{dm}^{-3}$, respectively. In the case of the column with $30-\mathrm{cm}$ thick sand, a significantly lower mean dissolved oxygen concentration was observed than for foams and $60-\mathrm{cm}$ thick sand. This indicates a very good oxygen saturation of filters filled with a spongy filling during the ten-month research cycle. Similar results were reported by Onodera et al. (2013), who stated the value of dissolved oxygen in the filtrate treated in the UASB reactor / DHS reactor system at the level of $33 \mathrm{mgO}_{2} \cdot \mathrm{dm}^{-3}$. In the research on grey sewage treatment, Tawfik et al. (2011) observed DO values of $3.1 \mathrm{mgO}_{2} \cdot \mathrm{dm}^{-3}$.

The results of the Kruskal-Wallis non-parametric test performed for the dissolved oxygen concentration in treated sewage throughout the entire period and in the individual test stages are presented in Table 2. Only in the case of stage II, for a hydraulic load of $114.6 \mathrm{~mm}^{3} \cdot \mathrm{mm}^{-2} \cdot \mathrm{d}^{-1}$, the test probability $\mathrm{p}$ was higher than 0.05 , which means that differences for DO values for the five columns are statistically insignificant. In all the other stages, the comparative column with $30-\mathrm{cm}$ thick sand differed statistically from the other columns.

The effectiveness of removing organic contaminations in individual columns for the analysed period of research is illustrated in Figure $4 \mathrm{a}-\mathrm{d}$.

For the brand new stiffened sponges (column 1 filling), the highest average rate of removal of organic compounds that are hard to decompose was observed during the filtration of sewage pre-treated by this filling in stage I (about 82\%) (see: Fig. 4a). For the new fillings, similarly high valueswere obtained by Tawfik (2011) during direct treatment of grey sewage and by Bundy et al. (2017) during filtration of sewage from households using sponges of different densities in the UASB-DHS system. In stage II, for column 1, the highest removal rate of easily decomposable organic substances was observed, which was on average 96.4\% (see: Fig. 4b).

In the case of columns filled with waste, there is a difference in the removal of organic compounds in favour of foams placed in rigid casings (column 3 ). In stage IV, the column with the highest hydraulic load

Table 2. Results of the Kruskal-Wallis test for the concentration of oxygen dissolved in purified sewage

\begin{tabular}{ccccc}
\hline $\begin{array}{c}\text { Stage I } \\
76.4 \mathrm{~mm}^{3} \cdot \mathrm{mm}^{-2} \cdot \mathrm{d}^{-1}\end{array}$ & $\begin{array}{c}\text { Stage II } \\
114.6 \mathrm{~mm}^{3} \cdot \mathrm{mm}^{-2} \cdot \mathrm{d}^{-1}\end{array}$ & $\begin{array}{c}\text { Stage III } \\
229.2 \mathrm{~mm}^{3} \cdot \mathrm{mm}^{-2} \cdot \mathrm{d}^{-1}\end{array}$ & $\begin{array}{c}\text { Stage IV } \\
76.4 \mathrm{~mm}^{3} \cdot \mathrm{mm}^{-2} \cdot \mathrm{d}^{-1}\end{array}$ & No division into stages \\
\hline 18.32226 & 8.728295 & 9.809668 & 12.62857 & 12.26825 \\
$\mathrm{p}=.0011$ & $\mathrm{p}=.0683$ & $\mathrm{p}=.0438$ & $\mathrm{p}=.0132$ & $\mathrm{p}=0.0155$ \\
$\{1 ; 6\},\{5 ; 6\}^{*}$ & $\{3 ; 6\}^{*}$ & $\{3 ; 6\}^{*}$ & $\{1 ; 6\},\{3 ; 6\}^{*}$ \\
\hline
\end{tabular}

statistically significant differences were marked in red

* in curly brackets are given pairs of columns that are statistically different from each other 

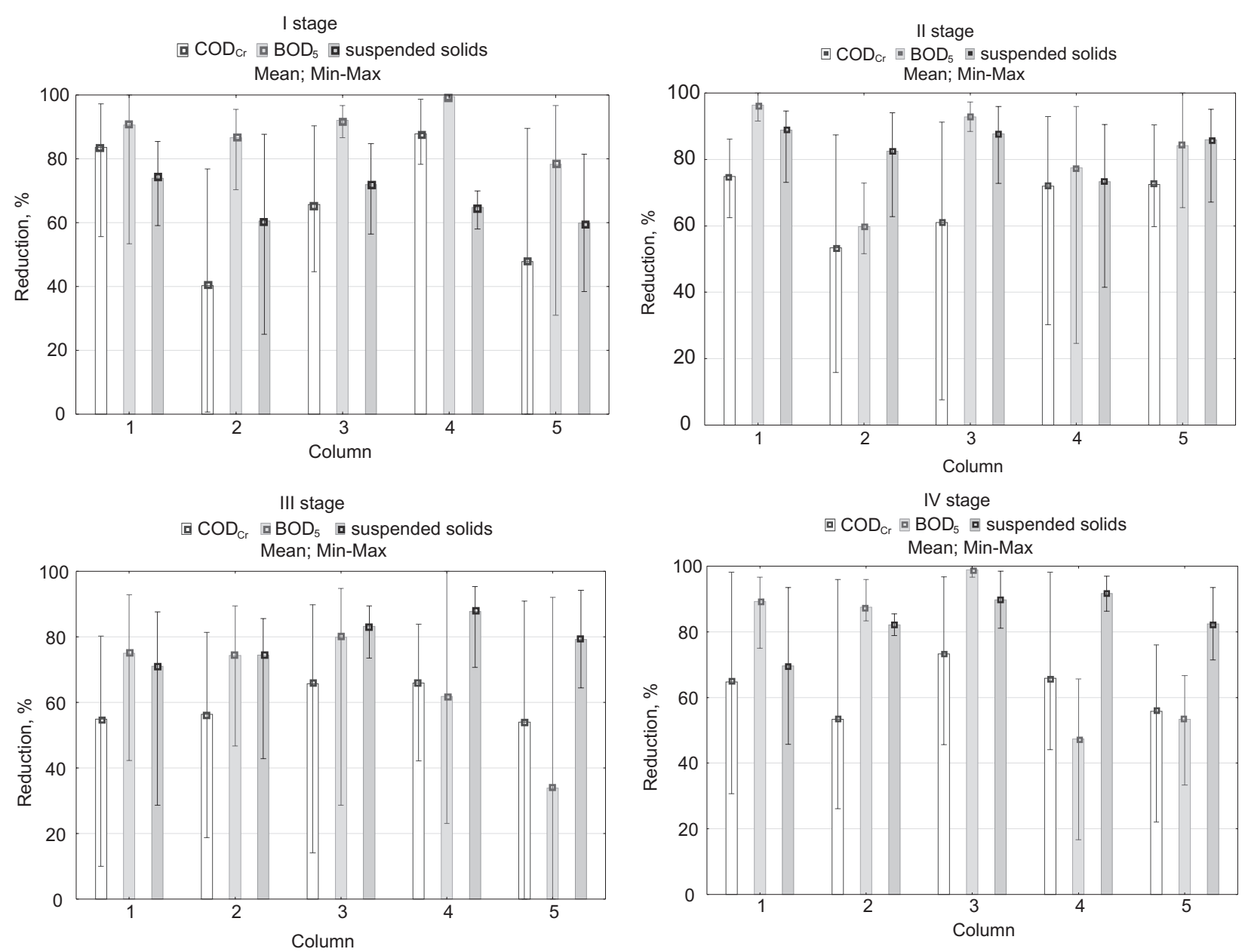

Fig. 4. The box-plot chart for the elimination of the CODCr and BOD5 index and total suspended solids in sewage treated in four research stages $(\mathrm{a}-\mathrm{d})$ for columns $1-5$

3 proved to be the most effective in terms of reducing both $\mathrm{COD}_{\mathrm{Cr}}(73.2 \%$ on average $)$ and $\mathrm{BOD}_{5}(98.9 \%$ on average) (see: Fig. 4d). Column 2 was characterised by a lower elimination of hardly and easily decomposable organic substances, amounting to $71 \%$ (stage III) and ca. $85 \%$ (stage I and IV) respectively. In the case of comparative column 5 filled with a 60 -cm thick sand, the highest average reduction of $\mathrm{COD}_{\mathrm{Cr}}$, by $88 \%$, was obtained in the first stage (see: Fig. 4a). Also, the best effects of sewage treatment of easily decomposable organic substances were observed, and they amounted to an average of $99.6 \%$. In the following stages, it was observed that the efficiency of column 4 gradually decreased to the values of $64.0 \%$ and $47.2 \%$, respectively.
Comparative column 5, filled with 30-cm thick sand, proved to be the least effective. It was characterised by a low rate of removal of hardly and easily decomposable organic substances, amounting to $72 \%$ and $78.3 \%$ on average in stage II.

Low values of removal efficiency of organic compounds could result from the presence of hardly decomposable organic compounds because the average quotient of the $\mathrm{COD}_{\mathrm{Cr}} / \mathrm{BOD}_{5}$ ratio in raw sewage was 1.95 (Miksch and Sikora, 2010; Bever et al., 1997).

During the whole research period, in the process of $\mathrm{BOD}_{5}$ removal from sewage with an increased ammonia nitrogen content, the column filled with waste foam placed in casings proved to be the most 
effective. High efficiency of the removal of easily biodegradable organic compounds indicated optimal conditions for the development of heterotrophic bacteria created in this filling. During 10 months of operation of the columns in variable hydraulic conditions, a similarly high degree of removal of total suspended solids was found. The effectiveness turned out to be the highest in column 3 and amounted to an average of $82.9 \%$.

Figure $5 \mathrm{a}-\mathrm{d}$ shows the degree of biogenic substance removal (ammonia nitrogen and orthophosphates) for the five columns in the analysed stages of the research.
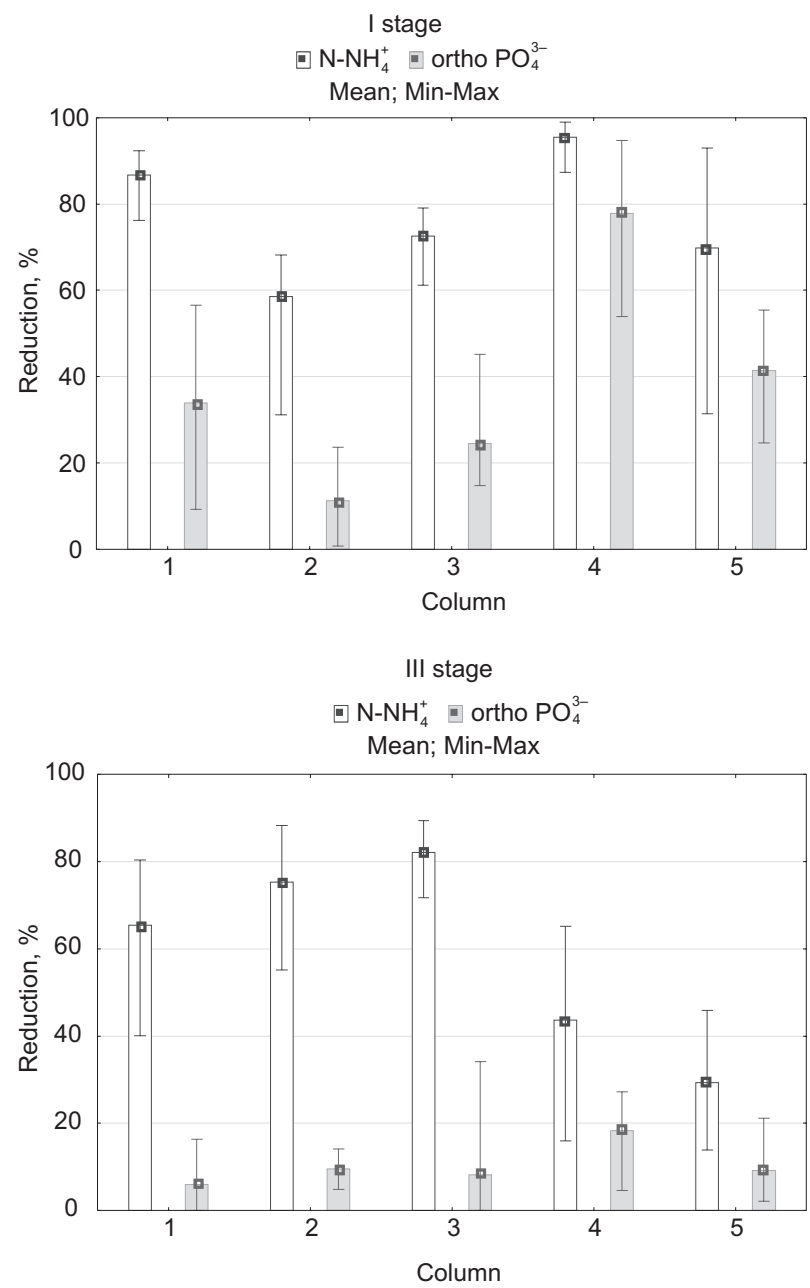

In the filtrate flowing from column 1 in stage I, it was found that the average ammonia nitrogen removal rate was $88 \%$ (see: Fig. $5 a$ ). The greater removal efficiency of $\mathrm{N}-\mathrm{NH}_{4}^{+}$for columns filled with waste was observed for foams placed in rigid casings. In stages II-IV, column 3 significantly reduced the concentration of ammonia nitrogen, by an average of $80 \%$. Column 2 proved to be less effective in the elimination of $\mathrm{N}^{-\mathrm{NH}_{4}+}$, yielding an average of $76.8 \%$ efficiency in stage IV. Similarly high values for the new fillings were obtained by Tawfik (2011) during direct treatment of grey sewage and by Bundy et al. (2017) during filtration in the UASB-DHS system of sewage
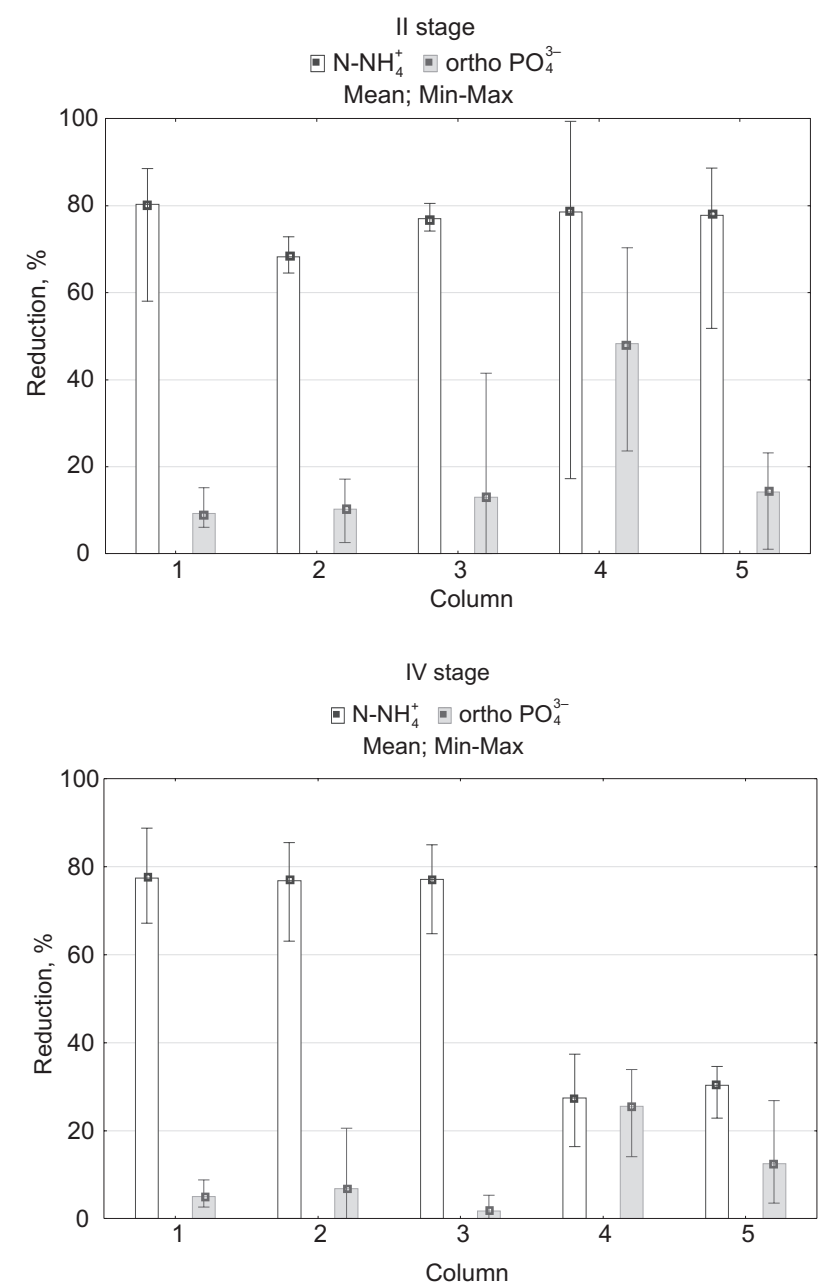

Fig. 5. The box-plot chart for the elimination of ammonia nitrogen and orthophosphates in sewage treated in four research stages (a-d) for columns 1-5 
from households using sponges of different densities. High porosity of both brand new and waste polyurethane material provided similar oxygen conditions in these filters, which were beneficial for the growth of both heterotrophic and nitrifying bacteria.

Comparative column 4 , filled with $60-\mathrm{cm}$ thick sand, worked effectively in stage I, removing ammonia nitrogen at an average level of $95.4 \%$. In the following stages, it was observed that the filter efficiency gradually decreased to $27.4 \%$. Due to the clogging of the pores of the sand, the transfer of oxygen and nutrients proved to be unfavourable and it deteriorated the conditions for the growth of both heterotrophic and nitrifying bacteria. In comparative column 5 filled with $30-\mathrm{cm}$ thick sand the lowest mean removal rate of $\mathrm{N}-\mathrm{NH}_{4}^{+}$was found, which decreased from $78 \%$ to $29 \%$ during the 10 months of research. The course of changes in the concentration of ammonia nitrogen in sewage coming from the septic tank and flowing to the research model, and in treated sewage in individual columns for four stages of research are depicted in Figure 6. The increase of $\mathrm{N}^{-\mathrm{NH}_{4}+}$ concentration in the outflow for the highest hydraulic load is particularly visible and amounted to $229.2 \mathrm{~mm}^{3} \cdot \mathrm{mm}^{-2} \cdot \mathrm{d}^{-1}$ (stage
III). Column 3 filled in the upper layer with waste foam in casings was characterised by the highest operation stability during 10 months of research.

The $60-\mathrm{cm}$ thick sand was characterised by the highest phosphorus sorption complex, which allowed for the highest elimination of orthophosphates (an average of $77.78 \%$ in stage I). During the 10 months of operation of the columns, depletion of the sorption complex was observed, which resulted in a gradual decrease of the elimination of $\mathrm{PO}_{4}^{3-}$. In the case of comparative columns 4 and 5 , it was the highest and amounted to approx. $70 \%$. In the initial period of research (see: Fig. 5a) for the double-layer sponge-sand columns, the average removal of orthophosphates amounted to about $36 \%$ (column 1). It dropped to a very low average value of $1.8 \%$ observed in the filtrate flowing out of column 3 (see: Fig. 5d).

As shown by studies by Wąsik and Chmielowski (2017) and Dacewicz et al. (2018), sand proved to be the most effective filling in the elimination of pathogenic bacteria due to grain size.

Due to the use of sand in all columns, a high removal of Escherichia coli and coliform bacteria occurred. The $100 \%$ average Escherichia coli removal rate was

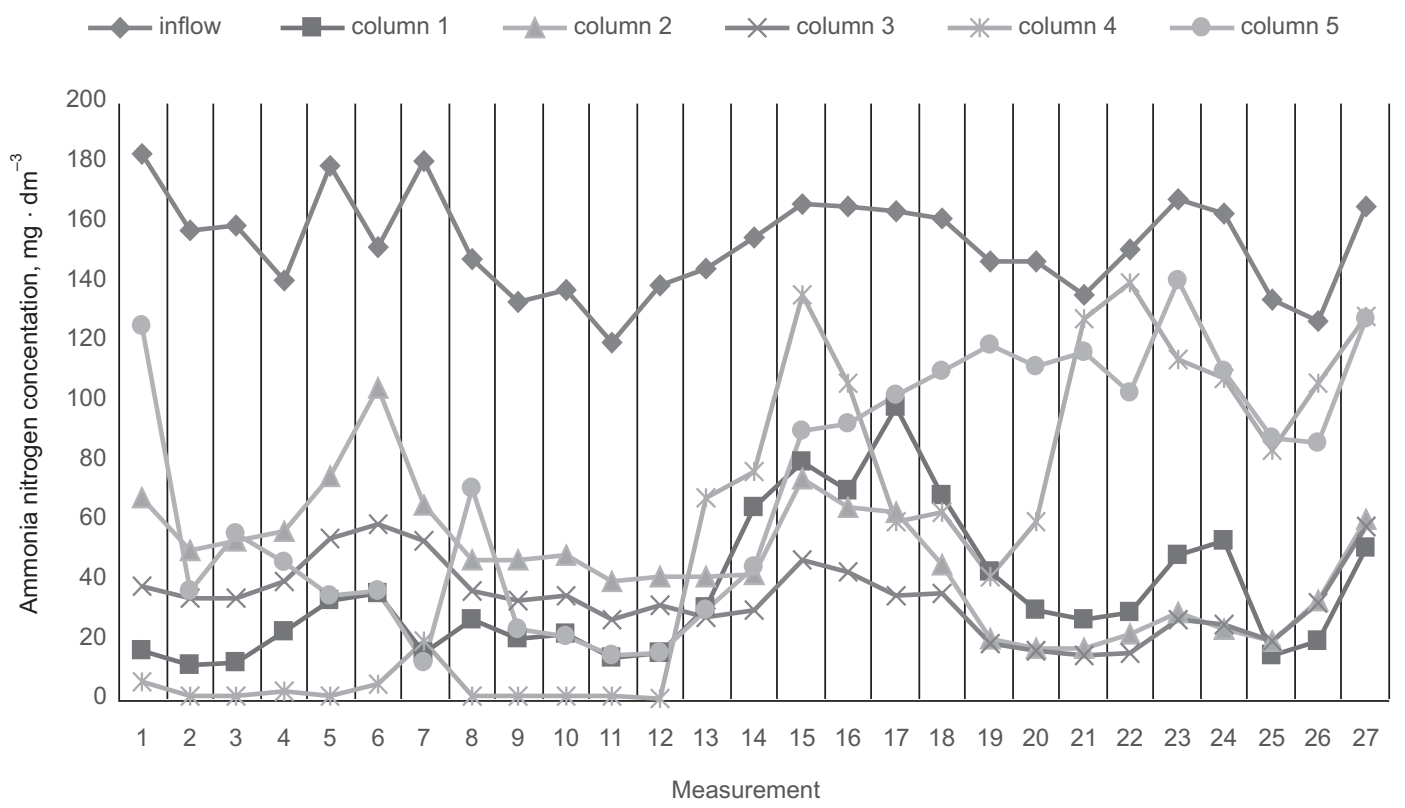

Fig. 6. Changes in ammonia nitrogen concentration in sewage flowing to the research model and in sewage purified in columns $1-5$ in the I-IV research stages 
found in stages I, II and IV for column 3. The highest $99.90 \%$ average elimination of coliform bacteria took place in stage IV (see: Fig 6d). The filling in the form of waste foams placed in casings created unfavourable conditions for the development of these bacteria. An additional bottom layer of $30 \mathrm{~cm}$ of sand proved to be effective in additional cleaning of the filtrate flowing through the foams.

In columns 1, 2 and 5, the average Escherichia coli removal was $99.95 \%$ (see: Fig. 7a), 99.93\% (see: Fig. 7d) and 99.45\% (see: Fig. 7a), respectively. In stage II, $96-97 \%$ of pathogenic coliform bacteria were removed on average in columns 1 and 2. The column in which there was a $60-\mathrm{cm}$ sand layer eliminated co- liform bacteria by an average of $88.7 \%$. In the column filled with only a $30-\mathrm{cm}$ sand layer, the lowest level of elimination of pathogenic bacteria was observed. For the highest hydraulic load (stage III), the average removal of Escherichia coli was 70.3\%, and for coliform bacteria only $35.8 \%$ (see: Fig. 7c).

The results obtained during the ten-month cycle of research on the use of a double-layer filter (in the form of polyurethane foams and sand) for the treatment of household sewage coming from the initial tank are comparable to that obtained for the anaerobic UASB reactor-DHS reactor system. Effectiveness of removing impurities in the system of new sponges the socalled „curtain” (second generation of DHS) was for
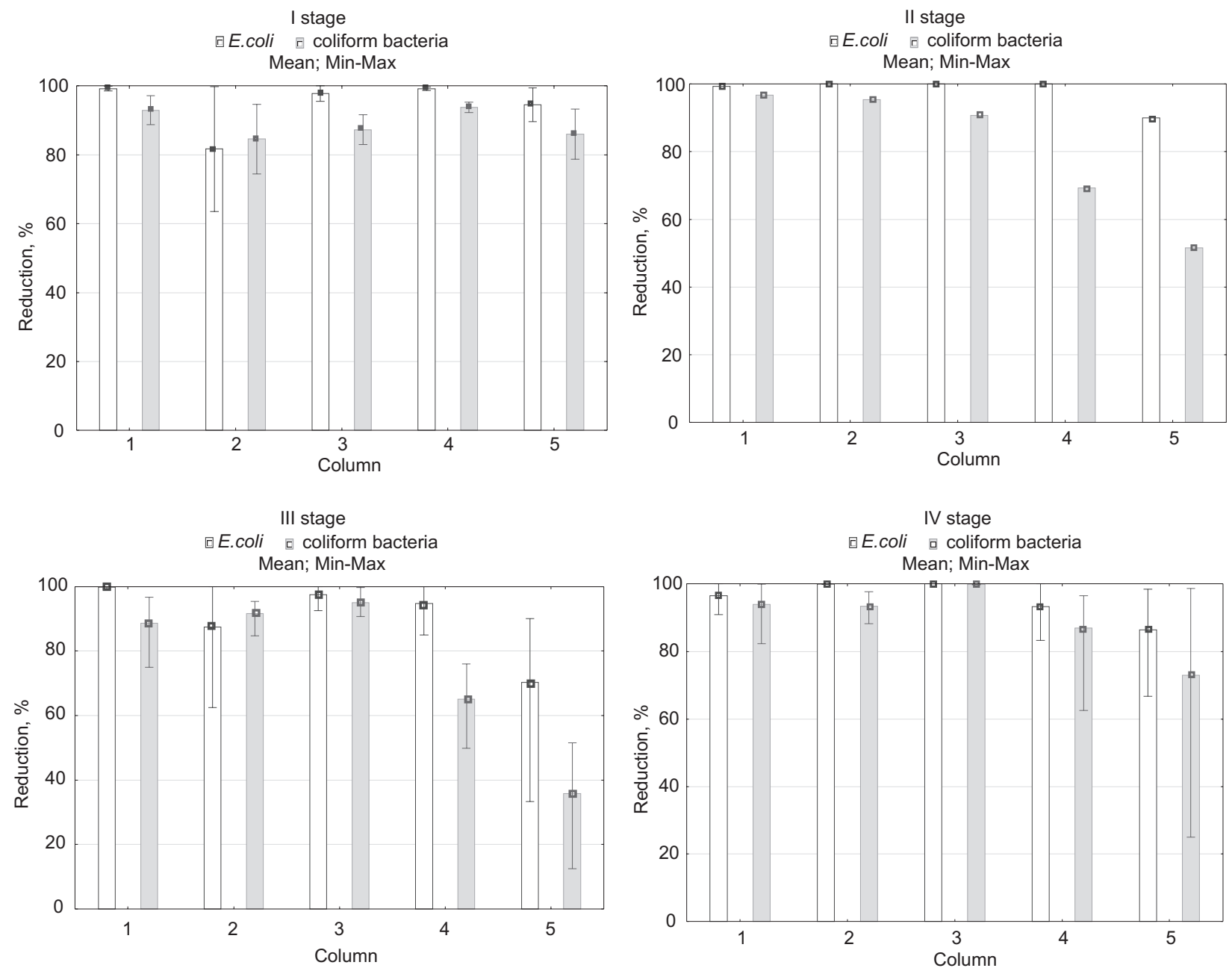

Fig. 7. The box-plot chart for the removal of Escherichia coli and coliform bacteria in purified sewage for columns 1-5 
$\mathrm{BOD}_{5}, \mathrm{COD}$ and total suspended solids respectively 94-97\%, 81-84\% and 63-79\% (Machdar et al., 2000). Studying the third and fourth generation of the DHS system, Tawfik et al. (2010) and Tandukar et al. (2007) achieved a reduction of $\mathrm{COD}, \mathrm{BOD}_{5}$ and ammonia nitrogen at the level of $95 \%, 98 \%$ and $86 \%$, respectively. It should be emphasised that the concentration of $\mathrm{N}^{-\mathrm{NH}_{4}}{ }^{+}$in sewage treated in the above mentioned system was about 5 times lower than in the current research using PUR waste.

The final stage of the analysis of the results was to determine whether the filtration bed filling is a factor significantly differentiating the value of $\mathrm{BOD}_{5}, \mathrm{COD}_{\mathrm{Cr}}$, total suspended solids, ammonia nitrogen, orthophosphates and pathogenic bacteria in treated sewage flowing out from individual columns of the research model The results of the nonparametric Kruskal-Wallis test, performed for variables characterised by the lack of normal distribution and the inhomogeneity of variance, are presented in Table 3.

In all columns, the removal of total suspended solids and of pathogenic bacteria due to the use of sand proved to be stable at individual stages of the research characterised by changing hydraulic conditions. For three stages (II, III and IV) there were no statistically significant differences at the assumed level of significance of 0.05 in the elimination of $\mathrm{COD}_{\mathrm{Cr}}$

Throughout the 10-month period of research and for most stages, statistically significant differences in the removal of easily biodegradable organic substances and biogenic compounds (ammonia nitrogen and orthophosphates) were found.

Analysing the above data it should be noted that filling the upper layer of the filter in the form of PUR foams with the lower sand layer proved to be the most effective in removing ammonia nitrogen from concen-

Table 3. Results of the Kruskal-Wallis test for 10-month research period based on contamination removal efficiency.

\begin{tabular}{|c|c|c|c|c|c|}
\hline $\begin{array}{l}\text { Reduction of the } \\
\text { contamination } \\
\text { index }\end{array}$ & Stage I & Stage II & Stage III & Stage IV & $\begin{array}{c}\text { No division into } \\
\text { stages }\end{array}$ \\
\hline $\mathrm{COD}_{\mathrm{Cr}}$ & $\begin{array}{c}15.70860 \\
\mathrm{p}=.0034 \\
\{1 ; 2\},\{2 ; 4\}^{*}\end{array}$ & $\begin{array}{l}3.636975 \\
p=.4574\end{array}$ & $\begin{array}{l}2.333165 \\
p=.6747\end{array}$ & $\begin{array}{l}2.057143 \\
p=.7252\end{array}$ & $\begin{array}{c}12.85139 \\
\mathrm{p}=.0120 \\
\{2 ; 4\}^{*}\end{array}$ \\
\hline $\mathrm{BOD}_{5}$ & $\begin{array}{l}10.54316 \\
p=.0322\end{array}$ & $\begin{array}{l}7.363593 \\
p=.1179\end{array}$ & $\begin{array}{c}9.302857 \\
\mathrm{p}=.0501 \\
\{3 ; 5\}^{*}\end{array}$ & $\begin{array}{c}12.12492 \\
\mathrm{p}=.0164 \\
\{3 ; 4\}^{*}\end{array}$ & $\begin{array}{c}14.35229 \\
\mathrm{p}=.0063 \\
\{1 ; 5\},\{3 ; 5\}^{*}\end{array}$ \\
\hline $\begin{array}{l}\text { Total suspended } \\
\text { solids }\end{array}$ & $\begin{array}{l}2.654545 \\
p=.6172\end{array}$ & $\begin{array}{l}5.316129 \\
p=.2564\end{array}$ & $\begin{array}{l}7.572717 \\
p=.1085\end{array}$ & $\begin{array}{l}2.400000 \\
p=.6626\end{array}$ & $\begin{array}{l}2.590562 \\
p=.6285\end{array}$ \\
\hline $\begin{array}{l}\text { Ammonia } \\
\text { nitrogen }\end{array}$ & $\begin{array}{c}21.34213 \\
\mathrm{p}=.0003 \\
\{1 ; 2\},\{2 ; 4\}^{*}\end{array}$ & $\begin{array}{c}9.806803 \\
p=.0438 \\
\{2 ; 5\}\end{array}$ & $\begin{array}{c}31.71916 \\
\mathrm{p}=.0000 \\
\{1 ; 5\},\{2 ; 4\},\{2 ; 5\},\{3 ; 4\},\{3 ; 5\}^{*}\end{array}$ & $\begin{array}{l}13.77143 \\
\mathrm{p}=.0081\end{array}$ & $\begin{array}{c}17.02664 \\
p=.0019 \\
\{1 ; 5\},\{3 ; 5\}^{*}\end{array}$ \\
\hline Orthophosphates & $\begin{array}{c}21.76868 \\
p=.0002 \\
\{2 ; 4\},\{2 ; 5\},\{3 ; 4\}^{*}\end{array}$ & $\begin{array}{c}13.35044 \\
p=.0097 \\
\{1 ; 5\},\{3 ; 5\}^{*}\end{array}$ & $\begin{array}{c}11.51775 \\
\mathrm{p}=.0213 \\
\{1 ; 4\}^{*}\end{array}$ & $\begin{array}{l}7.568485 \\
p=.1087\end{array}$ & $\begin{array}{c}27.07894 \\
p=.0000 \\
\{1 ; 4\},\{2 ; 4\},\{3 ; 4\}^{*}\end{array}$ \\
\hline Escherichia coli & $\begin{array}{l}4.900000 \\
p=.2977\end{array}$ & $\begin{array}{l}5.197674 \\
p=.2676\end{array}$ & $\begin{array}{l}6.056333 \\
p=.1950\end{array}$ & $\begin{array}{l}10.09326 \\
p=.0389\end{array}$ & $\begin{array}{c}23.19786 \\
p=.0001 \\
\{1 ; 5\},\{2 ; 5\},\{3 ; 5\}^{*}\end{array}$ \\
\hline $\begin{array}{l}\text { Coliform } \\
\text { bacteria }\end{array}$ & $\begin{array}{l}4.757576 \\
p=.3131\end{array}$ & $\begin{array}{l}8.072727 \\
\mathrm{p}=.0890\end{array}$ & $\begin{array}{l}8.919112 \\
p=.0632\end{array}$ & $\begin{array}{l}9.106847 \\
\mathrm{p}=.0585\end{array}$ & $\begin{array}{c}17.09485 \\
p=.0019 \\
\{1 ; 5\},\{3 ; 4\},\{3 ; 5\}^{*}\end{array}$ \\
\hline
\end{tabular}

statistically significant differences were marked in red

* in curly brackets are given pairs of columns that are statistically different from each other 
trated domestic sewage. The elimination of $\mathrm{N}^{-\mathrm{NH}_{4}^{+}}$ turned out to be at a similar level of $80 \%$ in three stages: II-IV. In the case of removal of pathogenic bacteria, the additional spongy material caused further reduction.

The comparative column with a $60-\mathrm{cm}$ thick sand fill was characterised by the highest $\mathrm{PO}_{4}^{3-}$ removal, which amounted to $40 \%$ on average over the entire research period. In the column with $30-\mathrm{cm}$ thick sand, the average elimination of orthophosphates was estimated at the level lower by half, i.e. $21 \%$.

Table 4 presents the values of actual pollutants indexes in treated sewage in individual columns against the normative values for treated sewage for sewage treatment plants with the $\mathrm{PE}<2000$ (Rozporządzenie ... 2014).

During the ten-month research period in filtrate from columns 1 and 3, there was a single exceedance of the $\mathrm{BOD}_{5}$ index, which occurred in the initial period of operation of the double-layered filter during the multiplication of microorganisms on the spongy filling. The most abnormal concentrations were observed in the comparative columns 4 and 5 and they were mainly related to the $\mathrm{BOD}_{5}$ index.

The use of the sand filling allowed adequate elimination of total suspended solids the value of which was lower than permissible in outflows from all the columns.

Table 4. Permissible and actual values of contamination indicators in purified sewage in individual columns

\begin{tabular}{|c|c|c|c|c|c|}
\hline \multirow{2}{*}{ Parameter } & \multirow{2}{*}{$\begin{array}{c}\text { Permissible value in } \\
\text { the outflow } X_{\text {per }} \\
{\left[\mathrm{mg} \cdot \mathrm{dm}^{-3}\right]}\end{array}$} & \multicolumn{3}{|c|}{$\begin{array}{l}\text { Actual value in the outflow } \\
\qquad\left[\mathrm{mg} \cdot \mathrm{dm}^{-3}\right]\end{array}$} & \multirow{2}{*}{$\begin{array}{c}\text { Number of exceedances } \\
\text { in } 10 \text {-month research } \\
\text { period }\end{array}$} \\
\hline & & Average $X_{\text {avg }}$ & Min. $X_{\min }$ & Max. $X_{\max }$ & \\
\hline \multicolumn{6}{|c|}{ Column 1} \\
\hline $\mathrm{COD}_{\mathrm{Cr}}$ & 150 & 55.0 & 1.6 & 127.0 & 0 \\
\hline $\mathrm{BOD}_{5}$ & 40 & 12.1 & 0.0 & 70.0 & 1 \\
\hline Total suspended solids & 50 & 12.0 & 5.20000 & 26.4 & 0 \\
\hline \multicolumn{6}{|c|}{ Column 2} \\
\hline $\mathrm{COD}_{\mathrm{Cr}}$ & 150 & 87.8 & & 148.0 & 0 \\
\hline $\mathrm{BOD}_{5}$ & 40 & 23.5 & & 92.0 & 3 \\
\hline Total suspended solids & 50 & 14.0 & & 30.0 & 0 \\
\hline \multicolumn{6}{|c|}{ Column 3} \\
\hline $\mathrm{COD}_{\mathrm{Cr}}$ & 150 & 57.6 & & 133.0 & 0 \\
\hline $\mathrm{BOD}_{5}$ & 40 & 11.4 & & 50.0 & 1 \\
\hline Total suspended solids & 50 & 9.3 & & 17.4 & 0 \\
\hline \multicolumn{6}{|c|}{ Column 4} \\
\hline $\mathrm{COD}_{\mathrm{Cr}}$ & 150 & 50.5 & & 106.0 & 0 \\
\hline $\mathrm{BOD}_{5}$ & 40 & 33.9 & & 90.0 & 6 \\
\hline Total suspended solids & 50 & 11.4 & & 27.4 & 0 \\
\hline \multicolumn{6}{|c|}{ Column 5} \\
\hline $\mathrm{COD}_{\mathrm{Cr}}$ & 150 & 80.3 & & 258.0 & 2 \\
\hline $\mathrm{BOD}_{5}$ & 40 & 31.8 & & 100.0 & 6 \\
\hline Total suspended solids & 50 & 11.2 & & 22.8 & 0 \\
\hline
\end{tabular}




\section{SUMMARY}

1. The column filled with stiffened PUR foams in the form of waste proved to be the most effective in reducing $\mathrm{BOD}_{5}$, total suspended solids, $\mathrm{N}-\mathrm{NH}_{4}^{+}$, Escherichia coli and coliform bacteria. The average reduction of these pollutants during the ten-month research cycle with variable hydraulic load was $88.0 \%, 82.9 \%, 77.6 \%, 98.8 \%$ and $95.0 \%$, respectively. The most effective in terms of $\mathrm{COD}_{\mathrm{Cr}}$ removal was the column filled with $60-\mathrm{cm}$ thick sand.

2. The use of foam cuttings with a porosity of $94.6 \%$ as the upper part of the filling of filters allowed the growth and development of microorganisms with a concentration of dissolved oxygen at a level sufficient to remove both organic and biogenic contaminants as well as total suspended solids.

3. Polyurethane foam wastes in the form of upholstery sponge cuttings placed in plastic casings were used in a double-layer vertical flow filter bed and it proved to be an effective way to treatment of domestic sewage coming from a septic tank. This uncomplicated technology is easy to control and economical due to the lack of need for additional aeration in comparison to the majority of existing oxygen systems and seems to be an interesting solution for the biological treatment of household sewage with an increased content of ammonia nitrogen.

4. The lower 30-cm quartz sand layer provided a very high level of pathogenic bacteria removal and can be used as a treated sewage disinfection stage in the top layer of foams.

\section{REFERENCES}

Bever, J., Stein, A., Teichmann, H., Brzeski, J., Kania, J., Olszewski, S. (1997). Zaawansowane metody oczyszczania ścieków: Eliminacja azotu i fosforu, sedymentacja i filtracja. Bydgoszcz: Oficyna Wyd. Projprzem-EKO.

Błażejewski, R. (1994). Przegląd indywidualnych systemów oczyszczania ścieków stosowanych w kraju i na świecie. Ogólnopolskie Sem. Szkol., Poznań.

Bundy C.A., Wu D., Jong M.C., Edwards S.R., Ahammad Z.S., Graham D.W. (2017). Enhanced denitrification in
Downflow Hanging Sponge reactors for decentralised domestic wastewater treatment. Bioresour. Technol., 226, 1-8.

Chmielowski, K., Dacewicz, E., Bedla, D., Mazur, R. (2018). Zastosowanie odpadów z tworzyw sztucznych w biofiltrach do oczyszczania ścieków bytowych. Przem. Chem., 97(9), 1456-1459.

Chmielowski, K., Slizowski, R. (2008). Defining the optima range of a filter bed's d10 replacement diameter in vertical flow sand filters. Environ. Prot. Eng., 34 (3), 35-42.

Dacewicz, E. (2018). Application of selective and porous materials for the removal of biogenic compounds and indicator bacteria from domestic wastewater, Acta Sci. Pol., Formatio Circumiectus. 17(2), 47-55.

Dacewicz, E., Chmielowski, K. (2018). The importance of media in wastewater treatment. In: I. Zhu (ed.), Sewage, IntechOpen, Rijeka, 35-54. DOI: http://dx.doi. org/10.5772/intechopen.75625.

Dacewicz, E., Kaczor, G., Bugajski, P. (2018). Wpływ wybranych miąższości filtrów piaskowych o przepływie pionowym na jakość oczyszczonych ścieków bytowych, Rocz. Ochr. Środ., 20 (2), 1546-1563.

Ehsas, A.F. (2013). Development of low cost community based domestic wastewater for Kandahar city, Afganistan. (Master thesis, Asian Institute of Technology, 2013.Thailand: School of Environ., Resources and Development).

Eurofoam...2018. http://www.eurofoam.pl/en, (dostęp 10.2018).

Heidrich Z., Kalenik M., Podedworna J., Stańko G. (2008). Sanitacja wsi. Warszawa: Wydawnictwo Seidel-Przywecki.

Henze M., Comeau Y. (2008). Wastewater characterization, in: M. Henze (ed.), Biological wastewater treatment: Principles modelling and design. London : IWA Publishing. 33-52.

Jowett, E.C., McMaster, M.L. (1995). On-site wastewater treatment using unsaturated absorbent biofilters. J. Environ. Quality, 24 (1), 86-95.

Kalenik, M. (2014). Skuteczność oczyszczania ścieków $\mathrm{w}$ gruncie piaszczystym $\mathrm{z}$ warstwą naturalnego klinoptylolitu. Ochr. Śr., 36(3), 43-48.

Khan, A.A., Gaur, R.Z., Kazmi, A.A., Lew B. (2013). Sustainable post treatment options of anaerobic effluent. In Biodegradation-Engineering and Technology. IntechOpen.

Metcalf \& Eddy (1991). Wastewater Engineering, Treatment, Disposal, Reuse. Third edition. New York: McGraw-Hill Ltd.

Machdar, I., Sekiguchi, Y., Sumino, H., Ohashi, A., Harada, H. (2000). Combination of a UASB reactor and a cu- 
rtain type DHS (downflow hanging sponge) reactor as a cost-effective sewage treatment system for developing countries. Water Sci. Technol., 42 (3-4), 83-88.

Miksch, K., Sikora, J. (2010), Biotechnologia ścieków. Warszawa: PWN.

Miyaoka, Y., Yoochatchaval, W., Sumino, H., Banjongproo, P., Yamaguchi, T., Onodera, T., Okadera, T., Syutsubo, K. (2017). Evaluation of the process performance of a down-flow hanging sponge reactor for direct treatment of domestic wastewater in Bangkok, Thailand, J. Environ. Sci. and Health, Part A, 52(10), 956-970, DOI: 10.1080/10934529.2017.1324708.

Onodera, T., Tandukar, M., Sugiyana, D., Uemura, S., Ohashi, A., Harada, H. (2014a). Development of a sixthgeneration down-flow hanging sponge (DHS) reactor using rigid sponge media. Bioresour. Technol., 152, 93.

Onodera, T., Yoochatchaval, W., Sumino, H., Mizuochi, M., Okadera, T., Fujita, T., Banjongproo, P., Syutsubo, K. (2014b). Pilot-scale experiment of down-flow hanging sponge for direct treatment of low-strength municipal wastewater in Bangkok, Thailand. Bioprocess Biosyst. Eng., 37 (1), 2281-2287.

Papiński, J., Żabski, L. (2012).|Oszczędzanie energii a zastosowanie pianek poliuretanowych, Izolacje, 2.

Pawełek, J., Bugajski, P. (2017). Rozwój przydomowych oczyszczalni ścieków w Polsce - zalety i wady rozwiązań. Acta Sci. Pol. Formatio Circumiectus, 16, 3-14.

Plastech...2019. https://www.plastech.pl/wiadomosci/Recykling-pianek-poliuretanowych-11342 (dostęp 02.2019).

Rozporządzenie...2014. Rozporządzenie Ministra Środowiska z dnia 18 listopada 2014 r. w sprawie warunków, jakie należy spełnić przy wprowadzaniu ścieków do wód lub do ziemi, oraz w sprawie substancji szczegól- nie szkodliwych dla środowiska wodnego. Dz.U. 2014 poz. 1800.

Spychała, M., Nieć, J. (2013). Impact of septic tank sludge on filter permeability. Environ. Prot. Eng., 39 (2), 77-89.

Tandukar M, Ohashi A, Harada H (2007). Performance comparison of a pilot scale UASB and DHS system and activated sludge process for the treatment of municipal wastewater. Water Res., 41, 2697-2705.

Tawfik A, El-Gohary F, Ohashi A, Harada H (2010a). Effect of sponge volume on the performance of down-flow hanging sponge (DHS) system treating UASB reactor effluent. Bioprocess Biosyst. Eng. J., 33, 779-785.

Tawfik A, Klapwijk A (2010b). Polyurethane rotating disc system for post-treatment of anaerobically pre-treated sewage. J. Environ. Manage., 91, 1183-1192.

Tawfik A, Wahab RA, Al-Asmer A. (2011). Effect of hydraulic retention time on the performance of down-flow hanging sponge system treating grey wastewater. Bioprocess Biosyst. Eng., 34, 767-776.

Tchobanoglous, G., Burton, F. L., Stensel, H. D. (2003). Wastewater engineering treatment and reuse (No. 628.3 T252s). Boston, US: McGraw-Hill Higher Education.

Ustawa...2012. Ustawa z dnia 14 grudnia 2012 r. o odpadach. Dz.U. 2013, poz. 21.

Uemura, S., Okubo, T., Maeno, K., Takahashi, M., Kubota, K. Harada, H., (2016). Evaluation of Water Distribution and Oxygen Mass Transfer in Sponge Support Media for a Down-flow Hanging Sponge Reactor, International J. Envir. Res., 10 (2), 265-272.

Wąsik E, Chmielowski K. (2017). Ammonia and indicator bacteria removal from domestic sewage in a vertical flow filter filled with plastic material. Ecol. Eng, 106, 378-384, DOI: https://doi.org/10.1016/j.ecoleng.2017.05.015.

\section{ZASTOSOWANIE DWUWARSTWOWEGO FILTRA PIASKOWEGO Z WARSTWA PIANEK PUR W PROCESIE OCZYSZCZANIA ŚCIEKÓW BYTOWYCH O PODWYŻSZONEJ ZAWARTOŚCI AZOTU AMONOWEGO}

\section{ABSTRAKT}

\section{Cel pracy}

Celem pracy było określenie możliwości zastosowania pianek poliuretanowych PUR jako górnej warstwy filtra piaskowego do oczyszczania ścieków bytowych, charakteryzujących się podwyższonym stężeniem azotu amonowego.

\section{Materiat i metody}

Porównano pracę złóż filtracyjnych wypełnionych fabrycznie nowym usztywnionym wypełnieniem lub rozdrobnionymi mechanicznie odpadami PUR. Określono skuteczność usuwania ze ścieków wstępnie oczysz- 
czonych w osadniku gnilnym związków organicznych i biogennych oraz zawiesin ogólnych i bakterii patogennych przy obciążeniu hydraulicznym zmieniającym się w zakresie od 31,8 do $229,2 \mathrm{~mm}^{3} \cdot \mathrm{mm}^{-2} \cdot \mathrm{d}^{-1}$.

\section{Wyniki i wnioski}

Wykazano, że po dziesięciu miesiącach pracy, filtry poliuretanowo-piaskowe, wypełnione w górnej warstwie kawałkami pianki poliuretanowej w osłonkach, osiągnęły wysoką skuteczność usuwania substancji organicznej (zmniejszenie $\mathrm{BZT}_{5}$ średnio o 88\% i $\mathrm{ChZT}_{\mathrm{Cr}}$ o 66\%). Zastosowanie odpadów z poliuretanu w górnej warstwie złoża filtracyjnego pozwoliło na usunięcie jonów $\mathrm{N}_{-} \mathrm{NH}_{4}^{+}$średnio $\mathrm{w} 78 \%$, podczas gdy jednowarstwowe filtry piaskowe okazały się równie skuteczne tylko w pierwszych dwóch etapach badań. Stwierdzono, że dodatkowe wypełnienie filtrów o przepływie pionowym w postaci ścinek pianki PUR umieszczonych w osłonkach, zapewniły korzystne warunki dla rozwoju zarówno bakterii heterotroficznych, jak i bakterii nitryfikacyjnych bez potrzeby dodatkowego napowietrzania. Zastosowana górna warstwa pianek w połączeniu z dolną warstwą piasku pozwoliła na bardzo wysokie usunięcie bakterii patogennych: Escherichia coli średnio w 98,8\%, natomiast bakterii colipodobnych średnio w 95,0\%.

Słowa kluczowe: pianki poliuretanowe, odpady, filtr piaskowy, oczyszczanie ścieków bytowych 